\title{
Molecular Identity of the Mechanotransduction Channel in Hair Cells: Not Quiet There Yet
}

\author{
Zizhen Wu and Ulrich Müller \\ Department of Molecular and Cellular Neuroscience, Dorris Neuroscience Center, Scripps Research Institute, La Jolla, California 92037
}

Hair cells in the mammalian cochlea are specialized mechanosensory cells that convert sound-induced vibrations into electrochemical signals. The molecular composition of the mechanotransduction channel underlying auditory perception has been difficult to define. The study of genes that are linked to inherited forms of deafness has recently provided tantalizing clues. Current findings indicate that the mechanotransduction channel in hair cells is a complex molecular machine. Four different proteins (TMHS/LHFPL5, TMIE, TMC1, and TMC2) have so far been linked to the transduction channel, but which proteins contribute to the channel pore still needs to be determined. Current evidence also suggests that the channel complex may contain additional, yet to be identified components.

Key words: hair cell; LHFPL5; mechanotransduction; tip link; TMC1; TMC2; TMHS; TMIE

\section{Introduction}

Hair cells in the mammalian cochlea are the receptor cells that convert sound-induced vibrations into mechanical signals. Hair cells carry their name because of their characteristic shape where a bundle of stereocilia (the "hair bundle") crowns the apical haircell surface (Fig. 1). The hair bundle is the mechanically sensitive organelle of hair cells. Within the bundle, the stereocilia are organized in rows of decreasing heights; they are connected by several types of extracellular filaments, including the tip links, which are thought to convey mechanical force onto the transduction channels (Fig. 1).

Electrophysiological recordings from hair cells provided the first evidence for the existence of an ion channel directly activated by mechanical force (Hudspeth and Corey, 1977). Subsequent studies demonstrated that the transduction channel in hair cells is a nonselective cation channel, admitting $\mathrm{Ca}^{2+}$ as well as monovalent ions (Corey and Hudspeth, 1979). This property has been explored to localize the channel in hair cells without knowledge of its molecular identity. High-speed $\mathrm{Ca}^{2+}$ imaging has shown that, upon mechanical stimulation of hair bundles in rodents, $\mathrm{Ca}^{2+}$ enters stereocilia near the lower end of tip links (Beurg et al., 2009), thus indicating that in mammals transduction chan-

\footnotetext{
Received April 26, 2016; revised May 18, 2016; accepted May 23, 2016.

The authors declare no competing financial interests.

This work was supported by National Institute on Deafness and 0ther Communication Disorders Grants DC005965, DC007704, and DC014713 to U.M., the Dorris Neuroscience Center, and the Skaggs Institute for Chemical Biology to U.M. We thank Xufeng Qiu, Christopher Cunningham, and Peter Barr-Gillespie for critical reading of the manuscript.

Correspondence should be addressed to Dr. Ulrich Müller, Dorris Neuroscience Center, Scripps Research Institute, La Jolla, CA 92037. E-mail: umueller@scripps.edu.

DOI:10.1523/JNEUROSCI.1149-16.2016

Copyright $\odot 2016$ the authors $\quad 0270-6474 / 16 / 3610927-08 \$ 15.00 / 0$
}

nels are present only at one end of this filament (Fig. 1). However, the identification of the molecular components of the ion channel that carry these currents has been challenging. Channel identification has been hampered by the scarcity of hair cells and the low expression levels of the mechanotransduction channels in stereocilia with only one or two functional channels per tip link (Ricci et al., 2003; Beurg et al., 2009).

Breakthroughs in the discovery of components of the mechanotransduction machinery of hair cells have been fueled by genetic studies. Deafness is the most common form of sensory impairment in humans, and mutations in $>80$ genes have been linked to the disease (http://hereditaryhearingloss.org/). The study of these genes initially led to the identification of the proteins that form the tip link (Fig. 1) (Siemens et al., 2004; Söllner et al., 2004; Ahmed et al., 2006; Kazmierczak et al., 2007). Subsequently, four integral transmembrane proteins, tetraspan membrane protein in hair cell stereocilia (TMHS; official nomenclature LHFPL5), transmembrane inner ear expressed gene (TMIE), and transmembrane channel-like proteins 1 and 2 (TMC1 and TMC2) have been closely linked to the transduction process (Fig. 1) (Kawashima et al., 2011; Xiong et al., 2012; Kim and Fettiplace, 2013; Kim et al., 2013; Pan et al., 2013; Beurg et al., 2014; Zhao et al., 2014). TMC1 and TMC2 have been proposed to be pore-forming subunits of the mechanotransduction channel (Pan et al., 2013), although compelling evidence supporting this conclusion has not yet been provided. We will summarize here our current knowledge on the molecular identification and function of putative components of the mechanotransduction channel in hair cells.

\section{TMC1 and TMC2: a link to deafness}

and mechanotransduction

TMC1 was initially identified through the positional cloning of the gene underlying the sensory deficits in families afflicted with 
specific forms of dominant and recessive deafness (Kurima et al., 2002). Mouse models carrying dominant and recessive mutations in TMC1 have also been described (Kurima et al., 2002; Vreugde et al., 2002). Studies in mice demonstrated that TMC1 and its close homolog TMC2 are expressed in hair cells in the inner ear, albeit each with a different developmental time course. In vestibular hair cells, TMC1 and TMC2 are coexpressed from developmental stages into adulthood. By contrast, in cochlear hair cells, TMC1 and TMC2 are coexpressed for the first few days after birth, but only TMC1 expression is maintained into adulthood (Kawashima et al., 2011).

The most conclusive evidence for the subcellular localization of TMC1 and TMC2 within hair cells was provided by a recent elegant study. Using BAC-transgenic mice that express TMC1 and TMC2 tagged with fluorescence proteins, it was shown that TMC1 and TMC2 are each concentrated near the lower end of tip links (Kurima et al., 2015), where the transduction channel is localized (Beurg et al., 2009). This localization was confirmed with antibodies to the endogenous TMC1 and TMC2 proteins (Kurima et al., 2015). The localization pattern is consistent with the observation that TMC1/2 interacts in heterologous cells with PCDH15 (Maeda et al., 2014; Beurg et al., 2015b), which forms the lower part of tip link (Fig. 2) (Kazmierczak et al., 2007).

Analysis of the sequences of TMC1 and TMC2 prompted speculation that the two proteins might encode subunits of the mechanotransduction channel in hair cells. Computer algorithms predict that TMC1 contains six putative transmembrane domains, as well as two additional hydrophobic domains that are not predicted to span the membrane (Kurima et al., 2002). The membrane topography of TMC1 has been experimentally verified (Labay et al., 2010); and with respect to the number of transmembrane domains (but not in other ways), the proteins resemble voltage-gated potassium channels and members of the Trp ion-channel family (Yool and Schwarz, 1991; Vannier et al., 1998). As one caveat to these studies, it has been difficult to express significant amounts of TMC1 and TMC2 at the cell surface of heterologous cells. The majority of the protein is retained in the ER and transmembrane topography has been mapped with epitope tags using ER-retained TMC1 (Labay et al., 2010). The same caveat applies to the biochemical studies that have demonstrated interactions between PCDH15 and TMC1/2. Because only minor amounts of $\mathrm{TMC} 1 / 2$ reach the cell surface, interactions with PCDH15 likely occur in an intracellular compartment (Maeda et al., 2014; Beurg et al., 2015b).

Electrophysiological analysis of cochlear and vestibular hair cells from Tmc1/2 double-mutant mice further solidified a link between the two proteins and the mechanotransduction process. Mechanically evoked transducer currents are abolished in cochlear and vestibular hair cells from mutant mice lacking both TMC1 and TMC2 (Kawashima et al., 2011; Pan et al., 2013). Transducer currents are also absent in cochlear hair cells from Tmc1 mutant mice but only $\sim \mathrm{P} 10$ when TMC2 is no longer expressed in the cochlea, indicative of functional redundancy between the two proteins (Kawashima et al., 2011; Pan et al., 2013). Transduction defects in hair cells lacking TMC1 and TMC2 can be rescued by overexpression of either TMC1 or

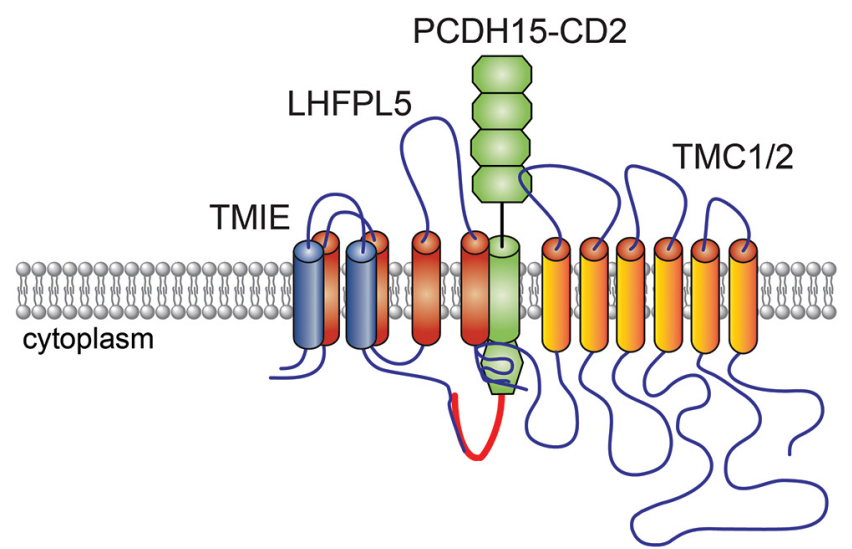

Figure 2. Model of the transduction channel complex of hair cells. TMC1/2, LHFPL5, and TMIE interact with PCDH15. TMIE specifically binds to the C terminus (red) unique to the PCDH15-CD2 isoform.

TMC2 alone, which suggests that the two proteins can function independently of each other to support transduction (Kawashima et al., 2011; Pan et al., 2013; Askew et al., 2015). Interestingly, mutations in Tmc1 but not Tmc2 have been shown to cause deafness (Kurima et al., 2002; Vreugde et al., 2002; Santos et al., 2005; Tlili et al., 2008), which can likely be explained by the fact that TMC2 is expressed only transiently in developing cochlear hair cells whereas TMC1 expression is maintained into adulthood (Kawashima et al., 2011).

\section{TMC1 and TMC2: pore-forming subunits of} mechanotransduction channels?

Single-channel recordings in developing outer hair cells (OHCs) from rodents have shown that the conductance of the transducer channel increases from the apex to the base of the cochlea, whereas the $\mathrm{Ca}^{2+}$ permeability of the channel decreases (Beurg et al., 2006; Kim and Fettiplace, 2013). No such changes are observed in inner hair cells (IHCs) (Beurg et al., 2006; Kim and Fettiplace, 2013). Because developing cochlear hair cells coexpress TMC1 and TMC2, several investigators asked whether conductance properties or ion selectivity of the mechanotransduction channel was altered in hair cells from mice carrying mutations affecting the expression of either TMC1 or TMC2. Changes in channel conductance and/or ion selec- 
tivity would further support a role for TMC1 and TMC2 as integral components of the transduction complex. Intriguingly, the tonotopic gradient in channel conductance is blunted in cochlear OHCs of mice lacking Tmc1 but not Tmc2 (Kim and Fettiplace, 2013; Beurg et al., 2014). Conversely, the $\mathrm{Ca}^{2+}$ selectivity of the transducer channel is affected in OHCs and IHCs lacking Tmc2 but not Tmc1 (Kim et al., 2013; Pan et al., 2013). These effects of Tmc1/2 mutations on the transducer current are curious in that TMC1 affects conductance and TMC2 affects $\mathrm{Ca}^{2+}$ selectivity in subtle ways (Kim and Fettiplace, 2013; Kim et al., 2013; Pan et al., 2013; Beurg et al., 2014). The findings suggest that the two proteins are functionally, albeit not entirely, redundant, which is somewhat surprising given the observation that expression of TMC1 alone or TMC2 alone can rescue transduction in hair cells lacking both TMC1 and TMC2 (Kawashima et al., 2011). Perhaps further detailed analysis of transducer currents in rescue experiments will reveal subtle differences that so far have escaped detection. One study also reported that the reduction in $\mathrm{Ca}^{2+}$ permeability and channel conductance is more pronounced in hair cells from mutant mice termed Beethoven that express a TMC1 protein with a missense mutation linked to progressive deafness (Pan et al., 2013). Together, these findings suggest that TMC1 and TMC2 are integral components of the mechanotransduction machinery of hair cells.

Holt and colleagues also developed a new method for mechanical stimulation of individual stereocilia to measure singlechannel events (Pan et al., 2013). Using this method, they reported a range of conductance for the mechanotransduction channel in IHCs. They concluded that differences in the stoichiometry of TMC1/2 may explain the variations in conductance they measured and that this is the underlying reason for the tonotopic changes in the conductance of the transducer channel along the cochlear tonotopic axis (Pan et al., 2013).

Despite these interesting findings, the extent to which TMC1 and TMC2 are pore-forming subunits of the transduction channel remains unclear. Adult cochlear hair cells only express Tmc1 (Kawashima et al., 2011). Thus, variations in the stoichiometry of $\mathrm{TMC} 1 / 2$ cannot explain tonotopic variations in transducer currents of the adult cochlea. In addition, using fluorescent-proteintagged TMC proteins expressed from BAC transgenes, Kachar and colleagues showed that, even in developing hair cells, TMC1 and TMC2 colocalize in only $\sim 30 \%$ of the fluorescence puncta observed in stereocilia (Kurima et al., 2015). Some stereocilia express only TMC1 or TMC2 (Kurima et al., 2015). These data make it less likely that TMC1 and TMC2 associate in various stoichiometries to form channels with different conductance states important for tonotopic gradients. It seems more likely that with their new stimulation and recording protocol, Holt and colleagues did not only record single-channel events but a composite of several channels, thus leading to the false impression of several conductance states of individual channels consisting of different subunits.

In addition, although measurements from the Beethoven mice performed by Holt and colleagues (Pan et al., 2013) suggest that TMC1 may be a pore-forming subunit of the transduction channel, the precise phenotype of Beethoven mice is not clear. A second study by the Fettiplace laboratory reported that in Beethoven mice there is a subtle change in $\mathrm{Ca}^{2+}$ permeability of the transducer channel similar to what Holt reported, but the Fettiplace group did not observe the changes in channel conductance described in the study from the Holt laboratory (Beurg et al., 2015a). This is a significant and important difference between the two studies because changes in conductance would link the protein more closely to the pore of the channel than small changes in
$\mathrm{Ca}^{2+}$ permeability alone. The reason for the difference in results is unclear but may be explained at least in part by the fact that the former study analyzed IHCs, whereas the latter study analyzed OHCs. In addition, the method used by Holt and colleagues to measure single-channel conductance involves deflection of an unidentified number of stereocilia within a hair bundle. The method has not been verified and thus might have given inaccurate results. Clearly, further studies are important to resolve this issue.

Notably, although changes in ion selectivity might be caused by mutations in pore residues of transduction channels, this is not universally true. For example, a point mutation in the hydrophobic domain of MinK leads to altered ion selectivity and a change in open channel block of a slowly activating potassium current in Xenopus oocytes (Goldstein and Miller, 1991). While these authors concluded from these data that MinK, a single pass transmembrane protein, is an ion channel, it was later shown that MinK associates with the potassium channel KvLQT1 (Kv7.1) without directly contributing to the pore (Barhanin et al., 1996; Sanguinetti et al., 1996). Another example is provided by the calcium release-activated calcium channel (CRAC1). STIM1 is not a pore-forming subunit of the CRAC1 channel and is localized in the ER. Nevertheless, the channel-associated STIM1 protein alters the ion selectivity of the CRAC1 channel (McNally et al., 2012). These findings demonstrate that accessory proteins can modulate the ion selectivity of an ion channel.

As an alternative, it has been proposed that TMC1/2 might form a vestibule of the transduction channel that shuttles ions toward the pore (Beurg et al., 2014; Marcotti et al., 2014). Mutations that cause variations in conductance could affect the charge of an external vestibule and ion flux toward the pore. A similar mechanism has been proposed as an explanation for the large conductance of the Slo $\mathrm{Ca}^{2+}$-activated $\mathrm{K}^{+}$channel, which contains an internal vestibule lined with glutamate residues. Replacement of glutamate with neutral residues drastically reduces the channel conductance (Brelidze et al., 2003). In the mechanotransduction channel of hair cells, there may be such a vestibule exposed to the extracellular environment, which could explain the high permeability of the channel for larger ions (Farris et al., 2004; van Netten and Kros, 2007). Further experiments are necessary to distinguish between a role for TMC1 and TMC2 as accessory or pore-forming subunits of the mechanotransduction channel in hair cells.

\section{The curious case of the "reverse-polarity" current}

In mature healthy hair cells, only deflections of the hair bundle in the direction of the longest stereocilia leads to an increase in the open probability of mechanically gated ion channels (Corey and Hudspeth, 1983). Hair bundles of immature hair cells are less directionally sensitive and deflections both in the direction of the longest stereocilia and in the opposite direction lead to an increase in channel open probability (Waguespack et al., 2007; Kindt et al., 2012; Kim and Fettiplace, 2013; Marcotti et al., 2014). The currents that are evoked by deflection toward the smallest stereocilia have been dubbed "reverse-polarity" currents (Kim et al., 2013). Curiously, when tip-links are broken, normal polarity currents can no longer be evoked but robust reverse-polarity currents emerge (Alagramam et al., 2001; Kim et al., 2013; Beurg et al., 2014; Marcotti et al., 2014). Whereas normal-polarity currents can no longer be evoked in hair cells from Tmc1/2 double mutant mice, these hair cells nevertheless show robust reversepolarity currents similar to hair cells lacking tip links (Kim et al., 2013; Beurg et al., 2014). It is intriguing that the kinetics of ap- 
pearance of the reverse-polarity current and disappearance of the normal-polarity current are inversely correlated (Kim et al., 2013; Beurg et al., 2016), suggesting that the channel carrying the forward current is converted into the channel carrying the reverse current. The two currents also show similar properties, including block by a high concentration of extracellular $\mathrm{Ca}^{2+}$ and by standard pharmacological channel inhibitors (Kim et al., 2013), although others have emphasized the differences in the two currents (Marcotti et al., 2014).

Recent findings suggest that the reverse-polarity current is carried by an ion channel localized to the apical surface of the cell body of hair cells with highest concentration near the longest stereocilia (Beurg et al., 2016). Interestingly, in Tmc1 and Tmc2 single mutants, fewer tip links are occupied with channels compared with Tmc2-deficient hair cells expressing mutant TMC1 (Pan et al., 2013). Thus, it has been proposed that TMC1/2 may not be the pore-forming subunits of the normal-polarity channel and instead function to transport channels into stereocilia and/or to stabilize interactions with tip links (Kim and Fettiplace, 2013; Kim et al., 2013; Beurg et al., 2014; Beurg et al., 2015b). In the absence of TMC1/2 or tip links, the pore-forming subunits may then relocalize to the apical cell surface. Notably, recent studies also show that the reverse-polarity current is more accurately described as a stretch-activated current that response to pulling forces applied to the apical membrane domain of the hair cell body (Beurg et al., 2016). Further studies are necessary to define the molecular identity of the ion channel carrying the reversepolarity current and its relationship to the normal-polarity current.

\section{Loose ends and open questions regarding TMC1 and TMC2}

TMC1 and TMC2 are intriguing proteins that are very likely closely linked to the transduction channel in hair cells. One might argue that the analysis of the effects of additional mutations in $T m c 1$ and $T m c 2$ on the properties of mechanotransduction currents in hair cells might clarify their role in mechanotransduction. For example, cysteine mutations can be engineered into the protein, and the effect of cysteine-modifying compounds on mechanotransduction can be evaluated (Akabas et al., 1992; Karlin and Akabas, 1998). However, these studies will probably not distinguish between a role of TMC1 and TMC2 as pore-forming or accessory channel subunits that form a vestibule. For these experiments to be conclusive, it first needs to be shown that TMC1 and TMC2 actually can form an ion-conducting pore. This could perhaps be achieved by crystallography or cryoelectron microscopy but would be more convincingly established by showing that TMC1 and TMC2 form pores following their expression in heterologous cells and ultimately in lipid bilayers. Attempts have so far failed to demonstrate that heterologous expression of TMC1 and TMC2 can confer mechanical sensitivity on native cells (Kawashima et al., 2011; Zhao et al., 2014). This failure has been attributed in large part to the inability of TMC1 and TMC2 to be efficiently shuttled to the cell-surface or heterologous cells; most of the protein remains in the ER (Labay et al., 2010). The fact that TMC1 and TMC2 can be transported to the tips of stereocilia (Kurima et al., 2015) suggests that the proteins are capable of being inserted into the plasma membrane; heterologous cells might lack critical chaperones or transport components. A Tmc ortholog in worm has been reported to be necessary for salt sensation and to generate a sodium-sensitive channel when expressed in heterologous cells (Chatzigeorgiou et al., 2013). However, others have shown that the phenotype of nematodes with mutations in Tmcl is complex and pleiotropic, with perturbations of sexual and metabolic function without an obvious specific role in sensory transduction (Zhang et al., 2015). Thus, further studies are necessary to show whether TMC proteins encode ion channels and whether they can be activated by mechanical force.

\section{The tetraspan protein LHFPL5 and mechanotransduction}

Recent studies have taken advantage of a large collection of genetically modified mice obtained from ENU mutagenesis screens and of mice genetically engineered to carry specific mutations to identify mouse lines that are deaf and have defects in mechanotransduction. Using this strategy, Xiong et al. (2012) demonstrated that mutations in Lhfpl5, also known as Tmhs, cause deafness and lead to a nearly $90 \%$ reduction in mechanotransduction in cochlear hair cells. LHFPL5 is a protein with four transmembrane domains that directly binds to PCDH15 (Xiong et al., 2012). Consistent with the biochemical data, LHFPL5 localizes in hair cells near the lower end of tip links (Xiong et al., 2012). Subsequent studies demonstrated that LHFPL5 regulates the transport of PCDH15 into stereocilia, thereby controlling the efficiency of tip-link formation (Xiong et al., 2012). In addition, LHFPL5 directly affects the properties of the transduction channel. Single-channel recordings demonstrated that, in the absence of LHFPL5, the conductance of the transduction channel is reduced and adaptation is severely impaired (Xiong et al., 2012). These findings are consistent with the model that LHFPL5 is a subunit of the mechanotransduction channel. LHFPL5 alone cannot be an essential part of the pore, however, because substantial mechanically evoked currents can still be recorded in hair cells lacking LHFPL5 (Xiong et al., 2012). Interestingly, LHFPL5 shares certain features with the TARP subunits of AMPA receptor. Like LHFPL5, TARPs have four transmembrane domains and they regulate both the transport of the pore-forming subunits of AMPA receptors and channel conductance (Jackson and Nicoll, 2011). In analogy, LHFPL5 may act as a TARP-like protein for the transduction channel and allosterically modulate the properties of the pore-forming subunits (Xiong et al., 2012). However, it can at present not be excluded that LHFPL5 might also contribute to the pore of the transduction channel. An instructive example is provided by the swell channel that is regulated by osmotic changes (Qiu et al., 2014; Voss et al., 2014; Syeda et al., 2016). The swell channel is a heteromeric channel consisting of several proteins with four transmembrane domains where subunit composition affects the properties of the ion channel (Syeda et al., 2016). Interestingly, LHFPL5 is a member of a small gene family (Longo-Guess et al., 2005), but the function of other members of this family in hair cells has not yet been reported. Alternatively, LHFPL5 might affect membrane properties locally, which is a function attributed to some tetraspans (Yáñez-Mó et al., 2009).

Recently, an intriguing link was established between LHFPL5 and TMC1. Although TMC1 does not bind directly to LHFPL5, TMC1 is no longer localized to the stereocilia of Lhflp5-deficient hair cells (Beurg et al., 2015b). Thus, both the transport of PCDH15 (Xiong et al., 2012) and TMC1 (Beurg et al., 2015b) depends on LHFPL5, suggesting that the proteins act in a molecular complex. Both LHFPL5 and TMC1 bind to PCDH15, which might mediate formation of the ternary complex, but other proteins might also contribute. In mice lacking Lhfpl5 and in mice lacking Tmcl, the tonotopic gradient in the conductance of the transducer channels is similarly blunted (Beurg et al., 2015b). Perhaps variations in levels of LHFPL5 and/or TMC1 along the 
cochlear axis could explain tonotopic differences in the conductance properties of the transducer channel.

\section{TMIE is essential for mechanotransduction by hair cells}

In search for additional components of the mechanotransduction machinery of hair cells, yeast two-hybrid screens were performed with proteins linked to transduction, including LHFPL5, PCDH15, and TMC1. One of the proteins that was identified as a binding partner for LHFPL5 and PCDH15 but not TMC1 was TMIE (Zhao et al., 2014). TMIE contains two predicted transmembrane domains and is linked to deafness in both humans and mice (Mitchem et al., 2002; Naz et al., 2002). Studies in zebrafish have shown that Tmiedeficient hair cells show degenerative changes and lack microphonic potential in response to vibratory stimulation, indicating that transduction is affected (Gleason et al., 2009). In murine hair cells, TMIE is localized in the tip-link region and essential for normal mechanotransduction without affecting the assembly of tip links (Zhao et al., 2014). The transduction defect in the Tmie-deficient hair cells can be rescued by acute reexpression of TMIE at early postnatal ages, demonstrating that mutations in Tmie directly affect transduction and do not act by a more general developmental mechanism (Zhao et al., 2014).

The localization of TMIE in hair cells and binding to PCDH15 and LHFPL5 suggest that TMIE is an integral component of the transduction machinery. PCDH15 is expressed in three major alternative spliced variants (PCDH15-CD1, -CD2, -CD3). The three splice variants are identical in their extracellular and transmembrane domains as well as in a short membrane proximal cytoplasmic domain that mediates interactions with TMC1/2 and LHFPL5 (Fig. 2) (Ahmed et al., 2006; Xiong et al., 2012; Maeda et al., 2014; Beurg et al., 2015b). However, they have distinct cytoplasmic C termini (Ahmed et al., 2006). Genetic studies suggest that PCDH15-CD2 is the PCDH15 isoform critical for mechanotransduction once hair cells have reached maturity (Pepermans et al., 2014), and biochemical data show that TMIE binds to the unique C terminus of PCDH15-CD2 (Fig. 2) (Zhao et al., 2014). TMIE also interacts with all three PCDH15 isoforms in a ternary complex through its interaction with LHFPL5 (Zhao et al., 2014). A TMIE fragment that consists of the C-terminal half that mediates interactions with PCDH15 and LHFPL5 acts as a dominant negative inhibiting interactions of TMIE with PCDH15. When this dominant negative TMIE fragment is expressed in wild-type hair cells, mechanotransduction is reduced (Zhao et al., 2014). Transduction is similarly reduced by overexpressing the CD2 domain of PCDH15, a protein fragment that affects interactions between TMIE and PCDH15-CD2 (Zhao et al., 2014). These findings suggest that TMIE acts in a ternary complex with LHFPL5 and PCDH15 to regulate transduction.

The relationship of TMIE to TMC1/2 is currently unclear. TMIE does not bind to TMC1/2, and the localization of TMC1/2 in stereocilia does not appear to be affected in hair cells lacking TMIE (Zhao et al., 2014). Similarly, LHFPL5 is still present in the stereocilia of Tmie mutant hair cells and tip links form in the mutant mice (Zhao et al., 2014). Thus, the mechanism by which TMIE affects transduction remains to be established. It is astonishing that mechanotransduction is completely abolished in hair cells lacking TMIE, yet all known components of the transduction complex in addition to TMIE appear to be present in their stereocilia. Perhaps TMIE affects the expression and/or localization of a yet to be identified component of the transduction machinery. Alternatively, TMIE might contribute to the channel pore. Indeed, proteins with two transmembrane domains, such as ENac/DEG in Caenorhabditis elegans, oligomerize to form a channel pore (Delmas and Coste, 2013). However, it has so far not been demonstrated that TMIE has ion channel properties, either alone or together with other proteins, such as LHFPL5 and TMC1/2 (Zhao et al., 2014).

In conclusion, the study of genes that are linked to hearing loss has provided important insight into the molecular machinery that is critical for mechanotransduction by hair cells. The study of the affected genes has also revealed an unexpected complexity in the transduction machinery of hair cells. Available evidence suggests that LHFPL5, TMIE, and TMC1/2 bind to PCDH15 and are integral components of a protein complex that is present at the lower end of tip links, where the mechanotransduction channel of hair cells is localized. The data also suggest that TMC1 and LHFPL5 have a critical function in establishing variations in the properties of the transduction channel along the tonotopic axis of the cochlea. However, the extent to which LHFPL5, TMIE, and TMC1/2 contribute to the channel pore is unclear. A recent study established that Piezo1, a mechanically gated ion channel in mammals (Coste et al., 2010), contains a miniature pore-forming module, an extracellular ion-selective module, and an intrinsic mechanotransduction module (Zhao et al., 2016). It is unknown whether the mysterious mechanotransduction channel in cochlear hair cells contains these modules within one protein or within separate molecular components. Ultimately, this question can likely only be conclusively answered by reconstitution of the mechanically gated ion channel in a heterologous system, such as heterologous cells or lipid bilayers. These experiments are important to demonstrate that the candidate proteins can form a channel pore. Given the complexity in the composition of the transduction complex in hair cells, reconstitution will be a difficult but essential task. Additional experiments, such as the identification of the channel pore using mutagenesis and subsequent expression of mutant channels with altered pore properties in hair cells, will be necessary as ultimate proof that a particular ion channel forms the pore of the mechanotransduction channel important for hearing.

Response from Dual Perspective Companion Authors-David P. Corey and Jeffrey R. Holt

The Perspective by Wu and Müller does a good job summarizing the important findings regarding the role of TMC proteins, and also summarizes their recent work on TMHS/ LHFPL5 and TMIE. As the two Perspectives cover much of the same material, it is not surprising that we agree on most of the key points. Disagreement about the specific roles of these proteins lies mostly in how we interpret and weigh the relative importance of some experiments.

One difference is in the importance of the reverse or anomalous current which is apparent when conventional transduction current is absent. The current has recently been shown to be activated by negative pressure on or near the apical hair-cell surface rather than by bundle deflection (Beurg et al., 2016). We agree with Wu and Müller that the anomalous current cannot be carried by TMC1 or TMC2, since it persists in TMC1/TMC2 knockouts. Although the pharmacological similarity of the two currents has lead some to suggest that the conventional and anomalous currents are carried by the same channels, we think the 
(modest) pharmacological similarity_never a strong argument with low-affinity blockers- does not offer much guidance for protein identity.

Müller and $\mathrm{Wu}$ also take issue with the single-channel measurements of Pan et al. (2013), suggesting that multiple channels may have been activated. Certainly the same may also be true for the Beurg et al. (2015) measurements, which used a fluid jet directed at the entire bundle. In both cases the standard single-channel criterion of selecting the smallest unitary current was used to avoid such artifact. Notably, both studies report a similar broad range of single channel conductances in wild-type auditory hair cells.

Pan et al. showed that single-channel conductance in neonatal wild-type inner hair cells varies among cells, mostly in the range between cells with just TMC1 and those with just TMC2. They suggested that heteromultimerization could produce such variation. Since older outer hair cells do not express TMC2 (Kawashima et al., 2011; Kurima et al., 2015), we agree with $\mathrm{Wu}$ and Müller that heteromultimerization with TMC2 cannot explain tonotopic variation in mature cells. Nonetheless, the point remains valid that molecular differences between TMC1 and TMC2 may produce differences in single-channel properties when co-expressed at neonatal stages.

Furthermore, the mean of three single-channel measurements from Bth inner hair cells reported by Beurg et al. (2015) was nearly identical to the mean of 17 measurements reported by Pan et al. (2013) when corrected for a 1.4-fold difference in amplitude, the latter a consequence of different external calcium concentrations. Pan et al. (2013) recorded from 25 inner hair cells that expressed wild-type $T m c 1$, which revealed $p<10^{-10}$ significance relative to Tmc1-Bth cells, and did not have the complication of concurrent TMC2 expression that Beurg et al. (2015) faced.

Finally, Müller and Wu feel strongly that nothing can be proven until a TMC protein in a heterologous cell or lipid bilayer is shown to create a mechanosensitive channel. We feel that this will be extremely difficult, given all the other proteins known to be essential for hair cell transduction. In the meantime, we suggest that site-directed mutagenesis, if rationally guided by sequence, may help confirm the location of TMC residues that line the channel pore.

Most importantly, we all agree that-after years of slow going-there has recently been remarkable progress in molecular identification of proteins in the hair-cell mechanotransduction complex. The next few years will be exciting indeed, as these proteins are assembled into an integrated model.

\section{References}

Beurg M, Golding AC, Ricci AJ, Fettiplace R (2016) Development and localization of reverse-polarity mechanotransducer channels in cochlear hair cells. Proc Natl Acad Sci U S A 113: 6767-6772. CrossRef Medline

Kawashima Y, Géléoc GS, Kurima K, Labay V, Lelli A, Asai Y, Makishima T, Wu DK, Della Santina CC, Holt JR, Griffith AJ (2011) Mechanotransduction in mouse inner ear hair cells requires transmembrane channel-like genes. J Clin Invest 121: 4796-4809. CrossRef Medline

Kurima K, Ebrahim S, Pan B, Sedlacek M, Sengupta P, Millis BA, Cui R, Nakanishi H, Fujikawa T, Kawashima Y, Choi BY, Monahan K, Holt JR,Griffith AJ, Kachar B (2015) TMC1 and TMC2 localize at the site of mechanotransduction in mammalian inner ear hair cell stereocilia. Cell Rep 12:1606-1617. CrossRef Medline

Pan B, Géléoc GS, Asai Y, Horwitz GC, Kurima K, Ishikawa K, Kawashima Y, Griffith AJ, Holt JR (2013) TMC1 and TMC2 are components of the mechanotransduction channel in hair cells of the mammalian inner ear. Neuron 79:504-515. CrossRef Medline

\section{References}

Ahmed ZM, Goodyear R, Riazuddin S, Lagziel A, Legan PK, Behra M, Burgess SM, Lilley KS, Wilcox ER, Riazuddin S, Griffith AJ, Frolenkov GI, Belyantseva IA, Richardson GP, Friedman TB (2006) The tip-link antigen, a protein associated with the transduction complex of sensory hair cells, is protocadherin-15. J Neurosci 26:7022-7034. CrossRef Medline

Akabas MH, Stauffer DA, Xu M, Karlin A (1992) Acetylcholine receptor channel structure probed in cysteine-substitution mutants. Science 258:307-310. CrossRef Medline

Alagramam KN, Yuan H, Kuehn MH, Murcia CL, Wayne S, Srisailpathy CR, Lowry RB, Knaus R, Van Laer L, Bernier FP, Schwartz S, Lee C, Morton CC, Mullins RF, Ramesh A, Van Camp G, Hageman GS, Woychik RP, Smith RJ, Hagemen GS (2001) Mutations in the novel protocadherin PCDH15 cause Usher syndrome type 1F. Hum Mol Genet 10:1709-1718. CrossRef Medline

Askew C, Rochat C, Pan B, Asai Y, Ahmed H, Child E, Schneider BL, Aebischer P, Holt JR (2015) Tmc gene therapy restores auditory function in deaf mice. Sci Transl Med 7:295ra108. CrossRef Medline

Barhanin J, Lesage F, Guillemare E, Fink M, Lazdunski M, Romey G (1996) K(V)LQT1 and lsK (minK) proteins associate to form the I(Ks) cardiac potassium current. Nature 384:78-80. CrossRef Medline

Beurg M, Evans MG, Hackney CM, Fettiplace R (2006) A large-conductance calcium-selective mechanotransducer channel in mammalian cochlear hair cells. J Neurosci 26:10992-11000. CrossRef Medline

Beurg M, Fettiplace R, Nam JH, Ricci AJ (2009) Localization of inner hair cell mechanotransducer channels using high-speed calcium imaging. Nat Neurosci 12:553-558. CrossRef Medline

Beurg M, Kim KX, Fettiplace R (2014) Conductance and block of haircell mechanotransducer channels in transmembrane channel-like protein mutants. J Gen Physiol 144:55-69. CrossRef Medline

Beurg M, Goldring AC, Fettiplace R (2015a) The effects of Tmc1 Beethoven mutation on mechanotransducer channel function in cochlear hair cells. J Gen Physiol 146:233-243. CrossRef Medline

Beurg M, Xiong W, Zhao B, Müller U, Fettiplace R (2015b) Subunit determination of the conductance of hair-cell mechanotransducer channels. Proc Natl Acad Sci U S A 112:1589-1594. CrossRef Medline

Beurg M, Golding AC, Ricci AJ, Fettiplace R (2016) Development and localization of reverse-polarity mechanotransducer channels in cochlear hair cells. Proc Natl Acad Sci U S A 113:6767-6772. CrossRef Medline

Brelidze TI, Niu X, Magleby KL (2003) A ring of eight conserved negatively charged amino acids doubles the conductance of BK channels and prevents inward rectification. Proc Natl Acad Sci U S A 100:90179022. CrossRef Medline

Chatzigeorgiou M, Bang S, Hwang SW, Schafer WR (2013) tmc-1 encodes a sodium-sensitive channel required for salt chemosensation in C. elegans. Nature 494:95-99. CrossRef Medline

Corey DP, Hudspeth AJ (1979) Ionic basis of the receptor potential in a vertebrate hair cell. Nature 281:675-677. CrossRef Medline

Corey DP, Hudspeth AJ (1983) Kinetics of the receptor current in bullfrog saccular hair cells. J Neurosci 3:962-976. Medline 
Coste B, Mathur J, Schmidt M, Earley TJ, Ranade S, Petrus MJ, Dubin AE, Patapoutian A (2010) Piezol and Piezo2 are essential components of distinct mechanically activated cation channels. Science 330:55-60. CrossRef Medline

Delmas P, Coste B (2013) Mechano-gated ion channels in sensory systems. Cell 155:278-284. CrossRef Medline

Farris HE, LeBlanc CL, Goswami J, Ricci AJ (2004) Probing the pore of the auditory hair cell mechanotransducer channel in turtle. J Physiol 558:769-792. CrossRef Medline

Gleason MR, Nagiel A, Jamet S, Vologodskaia M, López-Schier H, Hudspeth AJ (2009) The transmembrane inner ear (Tmie) protein is essential for normal hearing and balance in the zebrafish. Proc Natl Acad Sci U S A 106:21347-21352. CrossRef Medline

Goldstein SA, Miller C (1991) Site-specific mutations in a minimal voltage-dependent $\mathrm{K}^{+}$channel alter ion selectivity and open-channel block. Neuron 7:403-408. CrossRef Medline

Hudspeth AJ, Corey DP (1977) Sensitivity, polarity, and conductance change in the response of vertebrate hair cells to controlled mechanical stimuli. Proc Natl Acad Sci U S A 74:2407-2411. CrossRef Medline

Jackson AC, Nicoll RA (2011) The expanding social network of ionotropic glutamate receptors: TARPs and other transmembrane auxiliary subunits. Neuron 70:178-199. CrossRef Medline

Karlin A, Akabas MH (1998) Substituted-cysteine accessibility method. Methods Enzymol 293:123-145. CrossRef Medline

Kawashima Y, Géléoc GS, Kurima K, Labay V, Lelli A, Asai Y, Makishima T, Wu DK, Della Santina CC, Holt JR, Griffith AJ (2011) Mechanotransduction in mouse inner ear hair cells requires transmembrane channel-like genes. J Clin Invest 121:4796-4809. CrossRef Medline

Kazmierczak P, Sakaguchi H, Tokita J, Wilson-Kubalek EM, Milligan RA, Müller U, Kachar B (2007) Cadherin 23 and protocadherin 15 interact to form tip-link filaments in sensory hair cells. Nature 449:87-91. CrossRef Medline

Kim KX, Fettiplace R (2013) Developmental changes in the cochlear hair cell mechanotransducer channel and their regulation by transmembrane channel-like proteins. J Gen Physiol 141:141-148. CrossRef Medline

Kim KX, Beurg M, Hackney CM, Furness DN, Mahendrasingam S, Fettiplace R (2013) The role of transmembrane channel-like proteins in the operation of hair cell mechanotransducer channels. J Gen Physiol 142:493-505. CrossRef Medline

Kindt KS, Finch G, Nicolson T (2012) Kinocilia mediate mechanosensitivity in developing zebrafish hair cells. Dev Cell 23:329-341. CrossRef Medline

Kurima K, Peters LM, Yang Y, Riazuddin S, Ahmed ZM, Naz S, Arnaud D, Drury S, Mo J, Makishima T, Ghosh M, Menon PS, Deshmukh D, Oddoux C, Ostrer H, Khan S, Riazuddin S, Deininger PL, Hampton LL, Sullivan SL, et al. (2002) Dominant and recessive deafness caused by mutations of a novel gene, TMC1, required for cochlear hair-cell function. Nat Genet 30:277-284. CrossRef Medline

Kurima K, Ebrahim S, Pan B, Sedlacek M, Sengupta P, Millis BA, Cui R, Nakanishi H, Fujikawa T, Kawashima Y, Choi BY, Monahan K, Holt JR, Griffith AJ, Kachar B (2015) TMC1 and TMC2 localize at the site of mechanotransduction in mammalian inner ear hair cell stereocilia. Cell Rep 12:1606-1617. CrossRef Medline

Labay V, Weichert RM, Makishima T, Griffith AJ (2010) Topology of transmembrane channel-like gene 1 protein. Biochemistry 49:85928598. CrossRef Medline

Longo-Guess CM, Gagnon LH, Cook SA, Wu J, Zheng QY, Johnson KR (2005) A missense mutation in the previously undescribed gene Tmhs underlies deafness in hurry-scurry (hscy) mice. Proc Natl Acad Sci U S A 102:7894-7899. CrossRef Medline

Maeda R, Kindt KS, Mo W, Morgan CP, Erickson T, Zhao H, ClemensGrisham R, Barr-Gillespie PG, Nicolson T (2014) Tip-link protein protocadherin 15 interacts with transmembrane channel-like proteins TMC1 and TMC2. Proc Natl Acad Sci U S A 111:12907-12912. CrossRef Medline

Marcotti W, Corns LF, Desmonds T, Kirkwood NK, Richardson GP, Kros CJ (2014) Transduction without tip links in cochlear hair cells is mediated by ion channels with permeation properties distinct from those of the mechano-electrical transducer channel. J Neurosci 34: 5505-5514. CrossRef Medline

McNally BA, Somasundaram A, Yamashita M, Prakriya M (2012) Gated regulation of CRAC channel ion selectivity by STIM1. Nature 482: 241-245. CrossRef Medline

Mitchem KL, Hibbard E, Beyer LA, Bosom K, Dootz GA, Dolan DF, Johnson KR, Raphael Y, Kohrman DC (2002) Mutation of the novel gene Tmie results in sensory cell defects in the inner ear of spinner, a mouse model of human hearing loss DFNB6. Hum Mol Genet 11:1887-1898. CrossRef Medline

Naz S, Giguere CM, Kohrman DC, Mitchem KL, Riazuddin S, Morell RJ, Ramesh A, Srisailpathy S, Deshmukh D, Riazuddin S, Griffith AJ, Friedman TB, Smith RJ, Wilcox ER (2002) Mutations in a novel gene, TMIE, are associated with hearing loss linked to the DFNB6 locus. Am J Hum Genet 71:632-636. CrossRef Medline

Pan B, Géléoc GS, Asai Y, Horwitz GC, Kurima K, Ishikawa K, Kawashima Y, Griffith AJ, Holt JR (2013) TMC1 and TMC2 are components of the mechanotransduction channel in hair cells of the mammalian inner ear. Neuron 79:504-515. CrossRef Medline

Pepermans E, Michel V, Goodyear R, Bonnet C, Abdi S, Dupont T, Gherbi S, Holder M, Makrelouf M, Hardelin JP, Marlin S, Zenati A, Richardson G, Avan P, Bahloul A, Petit C (2014) The CD2 isoform of protocadherin-15 is an essential component of the tip-link complex in mature auditory hair cells. EMBO Mol Med 6:984-992. CrossRef Medline

Qiu Z, Dubin AE, Mathur J, Tu B, Reddy K, Miraglia LJ, Reinhardt J, Orth AP, Patapoutian A (2014) SWELL1, a plasma membrane protein, is an essential component of volume-regulated anion channel. Cell 157: 447-458. CrossRef Medline

Ricci AJ, Crawford AC, Fettiplace R (2003) Tonotopic variation in the conductance of the hair cell mechanotransducer channel. Neuron 40: 983-990. CrossRef Medline

Sanguinetti MC, Curran ME, Zou A, Shen J, Spector PS, Atkinson DL, Keating MT (1996) Coassembly of K(V)LQT1 and minK (IsK) proteins to form cardiac I(Ks) potassium channel. Nature 384:80-83. CrossRef Medline

Santos RL, Wajid M, Khan MN, McArthur N, Pham TL, Bhatti A, Lee K, Irshad S, Mir A, Yan K, Chahrour MH, Ansar M, Ahmad W, Leal SM (2005) Novel sequence variants in the TMC1 gene in Pakistani families with autosomal recessive hearing impairment. Hum Mutat 26:396. CrossRef Medline

Siemens J, Lillo C, Dumont RA, Reynolds A, Williams DS, Gillespie PG, Müller U (2004) Cadherin 23 is a component of the tip link in haircell stereocilia. Nature 428:950-955. CrossRef Medline

Söllner C, Rauch GJ, Siemens J, Geisler R, Schuster SC, Müller U, Nicolson $\mathrm{T}$ (2004) Mutations in cadherin 23 affect tip links in zebrafish sensory hair cells. Nature 428:955-959. CrossRef Medline

Syeda R, Qiu Z, Dubin AE, Murthy SE, Florendo MN, Mason DE, Mathur J, Cahalan SM, Peters EC, Montal M, Patapoutian A (2016) LRRC8 proteins form volume-regulated anion channels that sense ionic strength. Cell 164:499-511. CrossRef Medline

Tlili A, Rebeh IB, Aifa-Hmani M, Dhouib H, Moalla J, Tlili-Chouchène J, Said MB, Lahmar I, Benzina Z, Charfedine I, Driss N, Ghorbel A, Ayadi $\mathrm{H}$, Masmoudi S (2008) TMC1 but not TMC2 is responsible for autosomal recessive nonsyndromic hearing impairment in Tunisian families. Audiol Neurootol 13:213-218. CrossRef Medline

van Netten SM, Kros CJ (2007) Insights into the pore of the hair cell transducer channel from experiments with permeant blockers. Curr Top Membr 59:375-398. CrossRef Medline

Vannier B, Zhu X, Brown D, Birnbaumer L (1998) The membrane topology of human transient receptor potential 3 as inferred from glycosylation-scanning mutagenesis and epitope immunocytochemistry. J Biol Chem 273:8675-8679. CrossRef Medline

Voss FK, Ullrich F, Münch J, Lazarow K, Lutter D, Mah N, Andrade-Navarro MA, von Kries JP, Stauber T, Jentsch TJ (2014) Identification of LRRC8 heteromers as an essential component of the volume-regulated anion channel VRAC. Science 344:634-638. CrossRef Medline

Vreugde S, Erven A, Kros CJ, Marcotti W, Fuchs H, Kurima K, Wilcox ER, Friedman TB, Griffith AJ, Balling R, Hrabé De Angelis M, Avraham KB, Steel KP (2002) Beethoven, a mouse model for dominant, progressive hearing loss DFNA36. Nat Genet 30:257-258. CrossRef Medline

Waguespack J, Salles FT, Kachar B, Ricci AJ (2007) Stepwise morpholog- 
ical and functional maturation of mechanotransduction in rat outer hair cells. J Neurosci 27:13890-13902. CrossRef Medline

Xiong W, Grillet N, Elledge HM, Wagner TF, Zhao B, Johnson KR, Kazmierczak P, Müller U (2012) TMHS is an integral component of the mechanotransduction machinery of cochlear hair cells. Cell 151:12831295. CrossRef Medline

Yáñez-Mó M, Barreiro O, Gordon-Alonso M, Sala-Valdés M, SánchezMadrid F (2009) Tetraspanin-enriched microdomains: a functional unit in cell plasma membranes. Trends Cell Biol 19:434-446. CrossRef Medline

Yool AJ, Schwarz TL (1991) Alteration of ionic selectivity of a $\mathrm{K}^{+}$channel by mutation of the H5 region. Nature 349:700-704. CrossRef Medline
Zhang L, Gualberto DG, Guo X, Correa P, Jee C, Garcia LR (2015) TMC-1 attenuates C. elegans development and sexual behaviour in a chemically defined food environment. Nat Commun 6:6345. CrossRef Medline

Zhao B, Wu Z, Grillet N, Yan L, Xiong W, Harkins-Perry S, Müller U (2014) TMIE is an essential component of the mechanotransduction machinery of cochlear hair cells. Neuron 84:954-967. CrossRef Medline

Zhao Q, Wu K, Geng J, Chi S, Wang Y, Zhi P, Zhang M, Xiao B (2016) Ion permeation and mechanotransduction mechanisms of mechanosensitive piezo channels. Neuron 89:1248-1263. CrossRef Medline 